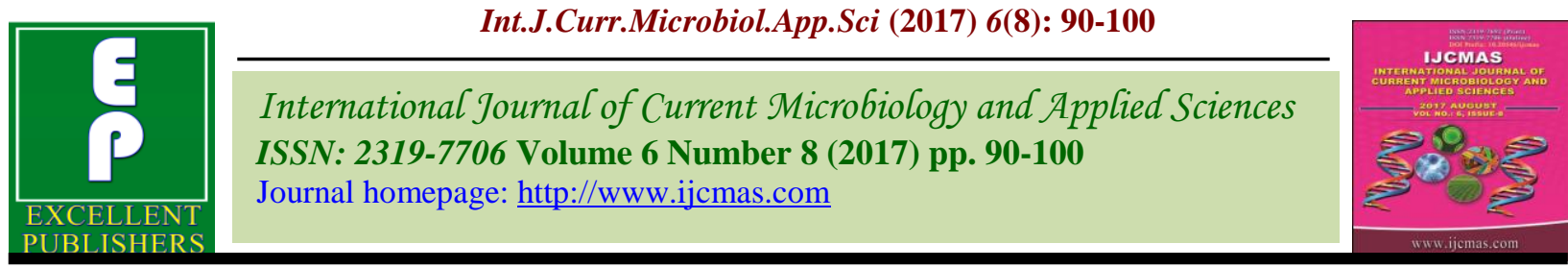

Original Research Article

https://doi.org/10.20546/ijcmas.2017.608.012

\title{
Extraction and Purification of Lipopolysaccharide of Klebsiella pneumoniae Isolates
}

\author{
Abeer Ghassan Munther Al-Agha* \\ Department of Microbiology, College of Veterinary Medicine, University of Diyala, Diyala, Iraq \\ *Corresponding author
}

A B S T R A C T

Keywords

Lipopolysaccharide, Klebsiella.

Article Info

Accepted: 04 June 2017 Available Online: 10 August 2017
The genus Klebsiella contains a number of opportunistic pathogens which cause several serious infections, including pneumonia, bacteremia, and urinary tract infections. Characteristically, Klebsiella spp. produce large mucoid colonies because of the synthesis of large amounts of capsular polysaccharide (CPS). The LPS molecule is a virulence determinant in Klebsiella pneumoniae. In the present work from a pathogenic urine sample Klebsiella pneumoniae was obtained, the lipopolysaccharide extracted and completely purified by gel filtration chromatography. The purity was confirmed through determination of protein concentration and carbohydrate.

\section{Introduction}

\section{Lipopolysaccharide}

The lipopolysaccharide (LPS) molecule is composed of three distinct sections; lipid A, a core polysaccharide and a side chain $\mathrm{O}$ antigen $(\mathrm{O}-\mathrm{Ag})$ polysaccharide. Nine $\mathrm{O}$ antigen types are distinguished in $K$. pneumoniae, $\mathrm{O} 1$ being the most frequent. The most important role of the $\mathrm{O}$-antigen is to protect $K$. pneumoniae from complement mediated killing (Podschun and Ullmann 1998; Hansen, Mestre et al., 1999; Brisse, Grimont et al., 2006).

Lipopolysaccharides are made up of a hydrophobic lipid (lipid A, which is responsible for the toxic properties of the molecule), a hydrophilic core polysaccharide chain, and a hydrophilic O-antigenic polysaccharide side chain. In most cases, Ospecific chains are built of repeating units of oligosaccharides which exhibit a strainspecific structural diversity. The sugar constituents, their sequence, and their mode of linkage determine the serological $\mathrm{O}$ specificity of respective strains. They are the main determinants of the classifications of the serotypes of Salmonella species. The CPS of $K$. pneumoniae is complex acidic polysaccharide consisting of repeating units of 3-6 sugars. In the past two decades a number of $K$. pneumoniae strains have been found to cause primary pyogenic liver abscess (PLA) (Wang et al., 1998; Yang et al., 2004; 
Wacharotayankun et al., 1993; Fung et al., 2002), with the capsular serotype $K_{1}$ being the most virulent (Mizuta et al., 1983). The $\mathrm{K}_{1}$ structure has been reported previously (lacking the acetyl-decoration on fucose) to possess two unique features- a fucose subunit (also found only in K54 and K63), and a unique cyclic 2,3-(S)-pyruvate appendix differing from a commonly seen 4,6-(R)pyruvate in CPS repeat units (Arakawa et al., 1995).

$K$. pneumoniae contains a capsule around its cell, known as $\mathrm{K}$ antigen. The reason for its pathogenicity is the thick capsule layer surrounding the bacterium, it is $160 \mathrm{~nm}$ thick of fine fibers that protrudes out from the outer membrane at right angles (Lawlor et al., 2005).

\section{Function and application}

The lipid A moiety has been identified as critical to the endotoxin activity of lipopolysaccharide. This was demonstrated by finding identical bioactive results, including endotoxic activity, between synthetic and natural-sourced E. coli lipid A preparations (Galanos et al., 1985). The active receptor for lipopolysaccharide has been identified as the CD14/TLR4/MD2 receptor complex, which promotes the secretion of proinflammatory cytokines including tumor necrosis factor- $\alpha$ and interleukin-1 (Palsson-McDermott and O'Neill, 2004). While the lipid A component is primarily responsible for immune response activation, the polysaccharide component of Salmonella enterica LPS is also necessary for $\mathrm{NF}-\kappa \mathrm{B}$ activation (Muroi and Tanamoto, 2002).

An important characteristic of K. pneumoniae growth is the production of capsular polysaccharide (CPS). A thick CPS layer, referred to as a capsule, envelops these bacteria and thwarts protective host defences (Simoons-Smit et al., 1986; Williams et al.,
1983; Williams and Tomas, 1990). Encapsulated $K$. pneumoniae also produces large quantities of cell-free CPS which is aggregated with toxic lipopolysaccharide (LPS) and contributes to pathogenicity (Batshon et al., 1963; Straus, 1987). Circulating cell-free CPS may also bind and neutralize antibodies that would otherwise attach to and opsonize bacteria (Cryz et al., 1986).

Bacterial pathogenicity has been shown to be due to different causes, including the structures of capsular polysaccharides (CPS; the $\mathrm{K}$ antigen), lipopolysaccharide (LPS; the $\mathrm{O}$ antigen), secreted toxins, drug resistance, and genetics (Abbott, 2003; Podschun and Ullman, 1998; Chang et al., 2000; Cheng et al., 1991). Klebsiella pneumoniae is an opportunistic pathogen of the Enterobacteriaceae and usually causes pneumonia or urinary tract infections (Chiu et al., 1988). In addition, the hospital outbreak of multidrug resistant Klebsiella spp., especially the so-called extended-spectrum beta lactamase (ESBL) and Klebsiella pneumoniae carbapenemase (KPC) subtypes has drawn much attention in recent years (Chiu et al., 1988; Fang et al., 2004; Ko et al., 2002).

The CPS of $K$. pneumoniae is complex acidic polysaccharide consisting of repeating units of 3-6 sugars. The type of sugars seems to correlate with the virulence, and 78 capsule types have been identified (Lin et al., 2004) In the past two decades a number of $K$. pneumoniae strains have been found to cause primary pyogenic liver abscess (PLA) (Wang et al., 1998; Yang et al., 2004; Wacharotayankun et al., 1993; Fung et al., et al., 2002), with the capsular serotype $\mathrm{K}_{1}$ being the most virulent (Mizuta et al., 1983). The $\mathrm{K}_{1}$ structure has been reported previously (lacking the acetyl-decoration on fucose) to possess two unique features- a fucose subunit (also found only in K54 and K63), and a 
unique cyclic 2,3-(S)-pyruvate appendix differing from a commonly seen 4,6-(R)pyruvate in CPS repeat units (Arakawa et al., 1995).

\section{Materials and Methods}

Solutions for determination of protein concentration (Bradford, 1976)

\section{Coomassie brilliant blue G-250 stain}

It was prepared by dissolving $0.1 \mathrm{~g}$ of Coomassie brilliant blue G-250 in $50 \mathrm{ml}$ of $95 \%$ ethanol, then $100 \mathrm{ml}$ of $85 \%$ phosphoric acid was added with agitation and the volume was completed to one litre with distilled water, then it was filtered through Whattman filter paper (No.1) and kept in a dark container.

\section{Bovine Serum Albumin (BSA)}

It was prepared by dissolving $0.1 \mathrm{~g}$ of $\mathrm{BSA}$ in Tris- $\mathrm{HCl}$ buffer, and then the volume was completed to $100 \mathrm{ml}$ with the same buffer.

\section{Sodium hydroxide (1M)}

It was prepared by dissolving $(40 \mathrm{~g})$ of sodium hydroxide in $(950 \mathrm{ml})$ of distilled water. Volume was completed to one liter.

Solutions and chemicals for purification of LPS

\section{Ion exchange}

\section{Sodium chloride ( $\mathrm{NaCl}), 0.25 \mathrm{M}$}

It was prepared by dissolving $3.65 \mathrm{~g}$ of sodium chloride in $250 \mathrm{ml}$ distilled water.

\section{DEAE-cellulose}

It was prepared by suspending $20 \mathrm{~g}$ of DEAEcellulose in 1leter distilled water.

\section{PBS buffer (0.1M pH 7.1)}

It was prepared by dissolving $8.5 \mathrm{gm}$ of PBS into $1000 \mathrm{ml}$ of distilled water and the $\mathrm{pH}$ was adjusted to 7.1 .

\section{Gel filteration chromatography}

\section{PBS buffer (0.1M pH 7.1)}

It was prepared by dissolving $8.5 \mathrm{gm}$ of PBS into $1000 \mathrm{ml}$ of distilled water and the $\mathrm{pH}$ was adjusted to 7.1 .

\section{Blue dextran 2000}

It was prepared by dissolving $0.06 \mathrm{~g}$ of blue dextran 2000 in $2 \mathrm{ml}$ of distilled water.

\section{Sepharose CL-6B}

It was prepared as recommended by the manufacturing company (Pharmacia).

\section{Chemical analysis of lipopolysaccharide}

Solutions for determination of protein concentration

\section{Phosphoric acid (85\%)}

It was prepared by the addition of $15 \mathrm{ml}$ of distilled water to $85 \mathrm{ml}$ of phosphoric acid.

\section{Sodium hydroxide (1M)}

It was prepared by dissolving (40g) of sodium hydroxide in $(950 \mathrm{ml})$ of distilled water. Volume was completed to one liter.

Coomassie brilliant blue G-250 (Bradford, 1976)

It was prepared by dissolving $0.1 \mathrm{~g}$ of Coommassie-brilliant blue G-250 in a solution composed of $100 \mathrm{ml}$ of phosphoric acid $85 \%$ and $50 \mathrm{ml}$ of absolute ethanol. Then 
the volume was completed to 1litter by distilled water. The solution was filtrated through filter paper Whatman No.1.

\section{Bovine serum albumin $(\mathrm{BSA})(100 \mu \mathrm{g} / \mathrm{ml})$}

It was prepared by dissolving $0.025 \mathrm{~g}$ of BSA in $25 \mathrm{ml}$ of distilled water. From this stock solution the concentrations 10, 20, 30, 40, 50, $60,70,80,90,100 \mu \mathrm{g} / \mathrm{ml}$ were prepared by diluting the stock in distilled water.

\section{Cell preparation}

Bacterial cells (K. Pneumoniae isolate) for lipopolysaccharide (LPS) extraction were cultured on 60 plates of nutrient agar, incubated at a temperature $37^{\circ} \mathrm{C}$ for a period 18-24 hr. Then harvested by spreader and kept in a funnel containing $200 \mathrm{ml}$ broth.

The inoculated flasks were incubated at $37^{\circ} \mathrm{C}$ for 24 hours with shaking at $150 \mathrm{rpm}$. After incubation, cultures were centrifuged (3000 rpm for 15 minutes), and the pellet was washed twice with phosphate buffer.

Cells were suspended in phosphate buffer containing $0.5 \%$ formalin $(\mathrm{pH}=7.2)$ and were kept at $4^{\circ} \mathrm{C}$ for 18 hours. After that, the cells were centrifuged (3000 rpm for 15 minutes) and washed with phosphate buffer.

Finally, cells were dried using cold acetone by ten times the sample's volume (Silipo et al., 2002).

\section{Destruction of bacterial cells}

The Klebsiella LPS was extracted by a method given by (Chandan and Fraser, 1994), which is summarized in the following steps:

The dried cells (20 g) were suspended in 50 $\mathrm{ml}$ phosphate buffer, and then $0.5 \mathrm{ml}$ of $0.5 \mathrm{M}$ EDTA solution was added. The suspension was then homogenized with magnetic stirrer for 2 minutes. The homogenized suspension was autoclaved and then left to cool.

After cooling, DNase and RNase solutions were added to at a final concentration of $1 \mu \mathrm{g} / \mathrm{ml}$ for each solution and incubated at $37^{\circ} \mathrm{C}$ for 10 minutes.

Proteinase $\mathrm{K}$ solution at a final concentration of $0.1 \mathrm{mg} / \mathrm{ml}$ was added and incubated at $56^{\circ} \mathrm{C}$ for 10 minutes and then the temperature was increased to $60^{\circ} \mathrm{C}$ for further 10 minutes. Finally the mixture was left to cool.

The extraction mixture was centrifuged at $10000 \mathrm{rpm}$ for 15 minutes. Two phases were formed; the aqueous phase (upper phase) was aspirated off with sterilized Pasteur's pipette and dialyzed for 4-6 days against distilled water at $4^{\circ} \mathrm{C}$ with changing the water every day. The dialyzed sample that contained endotoxin was lyophilized to obtain crude endotoxin.

\section{Determination of protein concentration}

Protein concentration was carried out using the Bradford method (1976) as follows: Add $20 \mu 1$ of sample (crude or purified) was mixed with $50 \mu \mathrm{l}$ of $1 \mathrm{M} \mathrm{NaOH}$ with continuous shaking for (2-3minutes).then (1ml) of Coomasie Brilliant Blue G-250 was added with shaking. Absorbance was measured at $595 \mathrm{~nm}$ by a spectrophotometer. A standard curve of bovine serum albumin was carried out using different concentrations $(10,20,30$, 40, 50, 60, 70, 80, 90 and $100 \mu \mathrm{g} / \mathrm{ml})$. Each was pipetted in duplicate in sterilized test tubes, then absorbency was plotted against the corresponding concentration of bovine serum albumin (Figure 1).

\section{Carbohydrate determination}

According to Dubois et al., (1956), the phenol-sulphuric acid method was used to determine carbohydrate concentration in LPS, 
in which the following steps were adopted: Standard solutions $(10,20,30,40,50,60,70$, $80,90$ and $100 \mu \mathrm{g} / \mathrm{ml})$ of glucose were prepared from the glucose stock solution (100 $\mu \mathrm{g} / \mathrm{ml})$, in order to plot the standard curve.

One $\mathrm{ml}$ of 5\% phenol was added to each tube and shaken well, followed by addition of $5 \mathrm{ml}$ of $\mathrm{H} 2 \mathrm{SO} 4$ was added to each tube. After wellshaking, the tubes were cooled in ice bath.

Absorbance was read at $490 \mathrm{~nm}$ for each tube, and then the standard curve was plotted.

The total carbohydrates concentration in LPS sample was determined by transferring $0.5 \mathrm{ml}$ of each gel-filtration fraction to a test tube, and then $0.5 \mathrm{ml}$ of $5 \%$ phenol and $2.5 \mathrm{ml}$ of $\mathrm{H} 2 \mathrm{SO} 4$ were added. The tubes were shaken well, and then cooled in ice bath. The absorbance was read at $490 \mathrm{~nm}$, and the total carbohydrate concentration was estimated from the standard curve using curve fitting equation (Fig. 2).

\section{Purification of LPS from $K$. pneumoniae (Jonson and perry, 1975)}

Ion exchange chromatography using diethyl aminoethyl- cellulose (DEAECellulose)

\section{Preparation of ion exchange column (DEAE-cellulose)}

The DEAE-Cellulose was prepared according to the method suggested by (Whitaker and Bernhard, 1972). A 20 gram of ion exchange resin was suspended in 1 liter distilled water, left in graduated cylinder to stagnate, after that the supernatant was removed, this step was repeated many times, until the supernatant becomes clear, the ion exchange resin was filtered by using Bukhner's funnel under vacuum (without drying the ion exchange resin), then the resin was activated in $250 \mathrm{ml}$ from buffer which contains $0.25 \mathrm{M}$ sodium hydroxide and $0.25 \mathrm{M}$ sodium chloride for 30 minutes, the resin was re-filtered and washed under vacuum using distilled water, then the resin was suspended in $250 \mathrm{ml}$ hydrochloride acid $0.25 \mathrm{M}$ with agitation for 30 minutes. After that, the resin was washed with distilled water under vacuum, the resin was suspended in PBS buffer $(0.1 \mathrm{M}, \mathrm{pH}$ 7.1) and the ion exchange resin was degassed by using vacuum. The resin was packaged gently in glass column $(3.5 \times 7 \mathrm{~cm})$, the equilibration was achieved by the same PBS buffer (Fig. 4).

\section{Separation through ion exchange resin (DEAE-cellulose) (Schutte et al., (23)}

DEAE-cellulose was packed in a column with dimensions of $(1.5 \times 25) \mathrm{cm}$. Ten ml solution (resultant extraction step) was loaded in ion exchange column carefully, the separated fractions were collected at flow rate 30 $\mathrm{ml} /$ hour (approximately, $5 \mathrm{ml}$ for each fraction), the wash was obtained by $0.05 \mathrm{M}$ phosphate buffer, $\mathrm{pH} 7.5$ (the same buffer used in equilibration).

The elution was achieved by the same buffer $(100 \mathrm{ml})$ of $0.05 \mathrm{M}$ phosphate buffer $(\mathrm{pH} 7.5)$ with gradual increase in concentration of $0.5 \mathrm{M}$ sodium chloride $(100 \mathrm{ml})$, the flow rate was $30 \mathrm{ml} /$ hour too, the protein concentration of the fractions was measured at wavelength $280 \mathrm{~nm}$ by UV-Visual Beam Spectrometer (Labomed) to the washed and eluted fractions, protein concentration then was calculated.

The presence of the LPS was estimated from each fraction of the major peaks. LPS was then measured the absorbance to every cool fractions at $280 \mathrm{~nm}$ to assessment the amount of whole protein in the fragement (Bruck et al., 1982) whereas at 490nm to calculation the carbohydrate amount according to (Dubios $e t$ al., 1956). 


\section{Gel filtration chromatography using Sepharose CL-6B}

\section{Column preparation}

One hundred milliliters of Sepharose CL-6B gel was washed with $0.05 \mathrm{M}$ phosphate buffer $(\mathrm{pH}$ 7.5) degassed under vacuum for 10 minutes for the removal of air bubbles that found in the gel, subsequently the gel suspension was poured into a glass column $(1.5 \times 80 \mathrm{~cm})$ and allowed the matrix to be settled down.

This gel is supplied swollen and ready to use as a suspension containing $20 \%$ ethanol as a preservative. The suspension is highly thick to be poured directly into a chromatography column therefore it must first be diluted with eluent to the required consistency (as described by company instruction Pharmecia).

\section{Column equilibration}

The gel was equilibrated with $0.05 \mathrm{M}$ phosphate buffer $(\mathrm{pH}$ 7.5) with flow rate $48 \mathrm{ml} / \mathrm{h}(4 \mathrm{ml} / 5 \mathrm{~min})$.

Purification of LPS through gel filtration chromatography using sepharose CL-6B (Chhibber and Vadehra, 1986):

A (5ml) sample of each concentrated partially purified LPS was added to the column (1.5 x87 cm) carefully using pasture pipette, Elution of $0.05 \mathrm{M}$ Phosphate buffer ( $\mathrm{pH} 7.5)$, $(5 \mathrm{ml})$ fraction was collected with flow rate of $60 \mathrm{ml} / \mathrm{hr}$.

The protein contents were estimated by measuring the absorbance at $280 \mathrm{~nm}$ by UVVisual Beam Spectrometer (Labomed) (Bruck et al., 1982), whereas at 490nm to calculation the carbohydrate amount according to (Dubios et al., 1956).
Determination of molecular weight of LPS by gel filtration chromatography

\section{Determination of the void volume of the column}

Sepharose CL-6B column was prepared and packed as described in A $2 \mathrm{ml}$ blue dextran 2000 solution was passed through the column, and of $0.05 \mathrm{M}$ phosphate buffer $(\mathrm{pH} 7.5)$ was added. Fractions of $5 \mathrm{ml}$ were collected.

The absorbency at $600 \mathrm{~nm}$ for each fraction was measured. The column void volume (Vo) was determined, by the estimation of the total volume of fractions as characterized with start point movement of the blue dextran to that of climax of absorbency of the blue dextran.

\section{Determination of LPS elution volume (Ve)}

Sepharose-6B column $(80 \times 1.5 \mathrm{~cm})$ was prepared, packed and Equilibrated for a second time. $5 \mathrm{ml}$ of purified LPS sample was passed through the column carefully, and equilibrated with $0.05 \mathrm{M}$ phosphate buffer $(\mathrm{pH}$ 7.5 ), with a flow rate of $50 \mathrm{ml} /$ hour.

Fractions of $5 \mathrm{ml}$ were collected. The elution volume $(\mathrm{Ve})$ was estimated for the separated fractions of purified exotoxin, by following the absorbance at $280 \mathrm{~nm}$.

\section{Measurement of standard protein elution volume (Ve)}

Different standard proteins were applied through Sepharose CL - 6B column, and then eluted with $0.05 \mathrm{M}$ phosphate buffer, with a flow rate of $50 \mathrm{ml} /$ hour, as shown in (Table $1)$.

The elution volume was estimated for each standard protein by following the absorbance for the separated fractions at wave length 280 
$\mathrm{nm}$. The $(\mathrm{Ve} / \mathrm{Vo})$ ratio was calculated for each standard protein and for the separated fractions of purified LPS. Then standardization was done by plotting the elution volume (Ve) of each standard proteins to the void volume (Vo) of the blue dextran 2000 (Ve/Vo) versus the log value of molecular weight (Stellwagen, 1990). The LPS molecular weight was accordingly calculated.

\section{Results and Discussion}

\section{Purification of LPS}

The collected fractions were first subjected for the determination of protein through reading the absorbance of each fraction at 280nm as submitted by (Bruck et al., 1982). Afterward, each fraction was handled according to Dubois et al., (1956) to calculate carbohydrate content, then the absorbance was read at a wave length of 490nm.The correlation between absorbency and fractions number of both concentration (protein and carbohydrate) was drawn in figure 3 .

\section{Determination of molecular weight}

The method of filtrating gel on a column Sepharose 6B was followed to estimate the molecular weight of the LPS, using a standard protein; by drawing the relationship between the logarithm of a standard protein molecular weight and the size of recovery/ size of Void (Ve/Vo) (Fig. 5).

Fig.1 A standard curve of bovine serum albumin

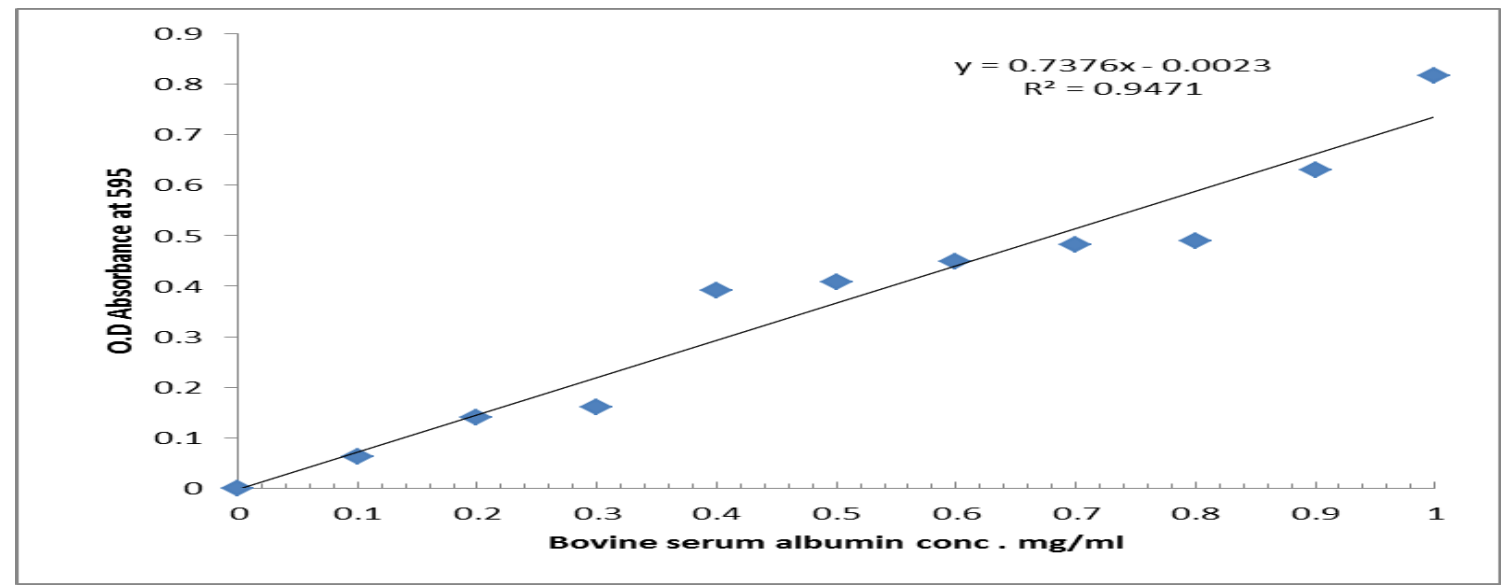

Fig.2 Standard curve of glucose

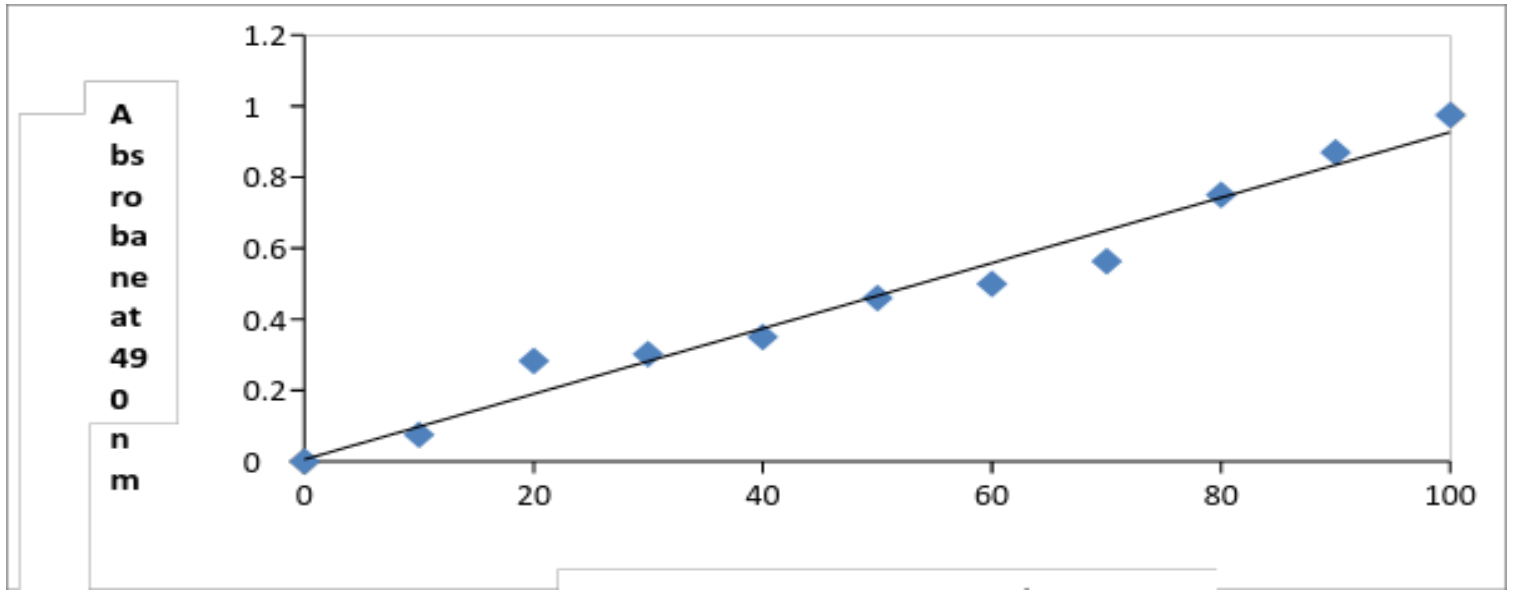




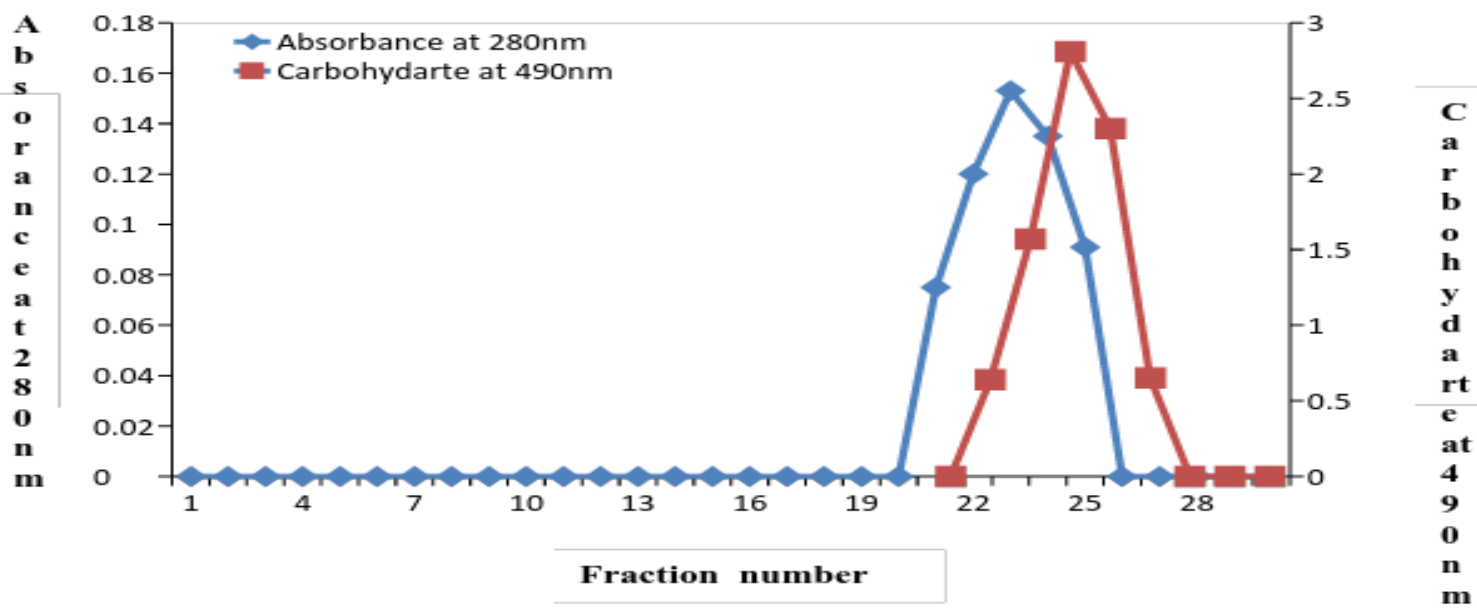

Figure (3): Gel filtration chromatography for purification LPS by using Sepharose $6 B$ column $1.5 \times 87 \mathrm{~cm}$. The collumn calibrated with phosphate buffer pH 7.5 , flow rate $60 \mathrm{ml} / \mathrm{hrs}$ and $5 \mathrm{ml} /$ fraction in the second time.

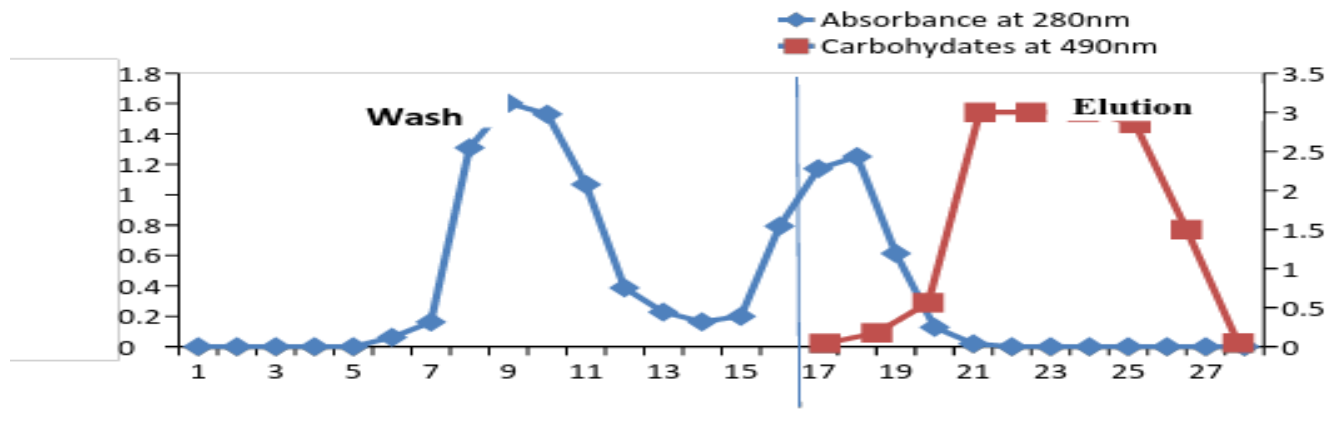

\section{Fraction number}

Figure (4): Gel filteration Chromatography for LPS of K.pneumonia throught Sepl $6 B$, column $1.5 \times 80 \mathrm{~cm}$, elution wasdone with PBS PH 7.2 at flow rate $60 \mathrm{ml} / \mathrm{h}, 5 \mathrm{ml}$ f fraction in the first time

Fig.5 Standardization of LPS from Klebsiella pneumoniae according to the ratio of Void volume and elution volume (Ve/Vo) ratio

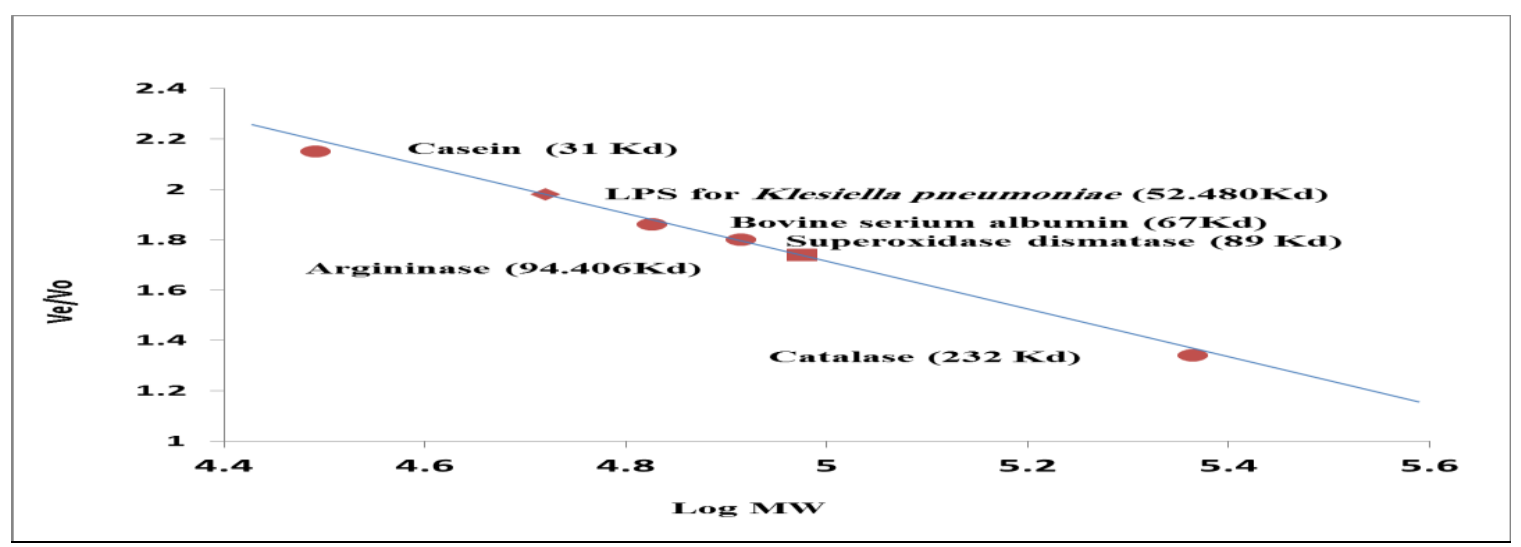


Table.1 Standard proteins used in determination of the molecular weight of lipopolysaccharide from $K$. Pneumoniae

\begin{tabular}{|c|l|}
\hline Molecular weight (KDaltons) & Standard proteins \\
\hline 31 & Casein \\
\hline 67 & Bovine Serum Albumin \\
\hline 89 & Superoxidase dismutase \\
\hline 94.40 & Argininase \\
\hline 232 & Catalase \\
\hline
\end{tabular}

Table.2 Standardization of LPS from Klebsiella pneumoniae according to the ratio of Void volume and elution volume (Ve/Vo) ratio

\begin{tabular}{|l|l|}
\hline Ve/Vo & Standard protein and purified LPS \\
\hline 2.15 & Casein \\
\hline 1.86 & Bovine Serum Albumin \\
\hline 1.8 & Superoxidase dismutase \\
\hline 1.74 & Argininase \\
\hline 1.341 & Catalase \\
\hline 1.98 & LPS \\
\hline
\end{tabular}

\section{Determination elution volume for standard protein}

Gel filtration was carried out for four of standard proteins (Table 2); absorption was measured at $280 \mathrm{~nm}$ in separated volumes to determine elution volume (V0) for each standard protein.

The relationship between elution volume percentages was blotted for each standard protein to the elution volume of blue dextrin (Ve/Vo) against molecular weight logarithm. This way helped measure enzymatic molecular weight.

\section{References}

Abbott, S. L., Cheung W. K. W. and Janda, J. M. (2003). The Genus Aeromonas: Biochemical Characteristics, Atypical Reactions, and Phenotypic Identification Schemes. J. Clin. Microbiol., 41(6): 2348-2357.

Arakawa Y., Wacharotayankun R., Nagatsuka T., Ito H., Kato N., and Ohta M. (1995).
Genomic organization of the Klebsiella pneumoniae cps region responsible for serotype K2 capsular polysaccharide synthesis in the virulent strain Chedid. J. Bacteriol., 177(7):1788-1796.

Batshon B. A., Baer H. and Shaffer M. F. (1963). Immunologic paralysis produced in mice by Klebsiella pneumoniae type 2 polysaccharide. J. Immunol., 90:121-126.

Bradford M. (1976). A rapid and sensitive method for the quantitation of microgram quantities of protein utilizing the principle of protein-dye binding. Annu. Biochem., 72: 248-254.

Brisse S., Grimont F. and Grimont P.A.D. (2006).The Genus Klebsiella. Prokaryotes, 6:159-196.

Bruck C., Portetelle D., Glineur C. and Bollen A. (1982). One-step purification of mouse monoclonal antibodies from ascitic fluid by DEAE affinity gel blue chromatography. J. Immunol. Methods, 53: 313-.319.

Chandan V. and Fraser A.D. (1994). Simple extraction of Campylobacter 
lipopolysaccharide and protein antigens and production of their antibodies in egg yolk. Inter.L.Food Micriobiol., 22:189-200.

Chang S.C., Fang C.T., Hsueh P.R., Chen Y.C. and Luh K.T. (2000). Klebsiella pneumoniae isolates causing liver abscess in Taiwan. Diagn. Microbiol. Infect. Dis., 37(4):279-284.

Cheng H. P., Chang F. Y., Fung C. P. \& Siu L. K. (2002). Klebsiella pneumoniae liver abscess in Taiwan is not caused by a clonal spread strain. $J$ Microbiol Immunol Infect., 35: 85-88.

Chhibber S. and Vadehra D. (1986). Purification and charachterization of Bacteriocin from Klebsiella pneaumoniae 158. J. Gen. Microbiol., 132(4): 1051-1054.

Chiu NC; Hang FY., Tsai TC. (1988). Urinary tract infections in children. Europe PMC; 30(4): 225-232.

Cryz Jr. S. J., Mortimer P. M., Mansfield V. and R.Germanier (1986). Seroepidemiology of Klebsiella pneumoniae bacteremic isolates and implications for vaccine development. J. Clin. Microbiol., 23:687-690.

Dubois M., Gilles K. A., Hamilton J. K., Rebers P. A. and Smith, F. (1956). Determination of sugars and related substances. Anal. Chem., 28: 350-356.

Fang CT., Lai SY., Yi WC; Hsueh PR; Liu KL. and Chang SC. (2007). Klebsiella pneumoniae genotype $\mathrm{K} 1$ : an emerging pathogen that causes septic ocular or central nervous system complications from pyogenic liver abscess. Clin.Infect.Dis., 45: 284-293.

Fung C. P., Chang F. Y., Lee S.C., Hu B.S., Kuo B.I., Liu C.Y., Ho M. and Siu L. K.(2002). A global emerging disease of Klebsiella pneumoniae liver abscess: Is serotype $\mathrm{K} 1$ an important factor for complicated endophthalmitis? Gut; 50(3):420-424.
Hansen D. S., Mestre F., Alberti S., Hernandez-Alles S., Alvarez D., Domenech-Sanchez A., Gil J., Merino S., Tomas J. M. and Benedi V. J. (1999). Klebsiella pneumoniae lipopolysaccharide $\mathrm{O}$ typing: Revision of prototype strains and O-group distribution among clinical isolates from different sources and countries. J. Clin. Microbiol; 37(1):56-62.

Johnson, K. G. and Perry, M. B. (1975). Improved techniques for the preparation of bacterial lipopolysaccarides. CAN. J. Microbiol., 22: 29- 34.

Ko W.C., Paterson D.L., Sagnimeni A.J., Hansen D.S., Von Gottberg A., Mohapatra S., Casellas J.M., Goossens H., Mulazimoglu L., Trenholme G., Klugman K. P., McCormack J.G. and $\mathrm{Yu}$ V.L.(2002). Community-acquired Klebsiella pneumoniae bacteremia: Global differences in clinical patterns. Emerg. Infect. Dis., 8(2):160-166.

Lawlor M., Hsu J;Rick P.and Miller V. (2005).Identification of Klebsiella pneumoniae virulence determinants using an intranasal infection model. Molecular Microbiology; 58(4):10541073.

Lin J.C., Chang F.Y., Fung C.P., Xu J.Z., Cheng H.P., Wang J.J., Huang L.Y. \& Siu L.K. (2004). High prevalence of phagocytic resistant capsular serotypes of Klebsiella pneumoniae in liver abscess. Microbes Infect; 6:1191-1198.

Mizuta L.G., Ohta M., Mori M., Hasegawa T., Nakashima I. and Kato N. (1983). Virulence for mice of Klebsiella strains belonging to the $\mathrm{O} 1$ group: Relationship to their capsular $(\mathrm{K})$ types. Infect. Immun., 40: 56-61.

Muroi M. and Tanamoto KI. (2002). The polysaccharide protein plays an indispensable role in Salmonella lipopolysacchride -Induced activity of NF-kB through human toll-like receptor 
4; 70(11): 6043-6047.

Palsson-Mcdermott EM. And o'Nell L. (2004). Signal transduction by the lipopolysaccharide receptor, Toll-like receptor-4. Immunology; 113:153-162.

Podschun R. and Ullmann U. (1998a). Klebsiella spp. as nosocomial pathogens: Epidemiology, taxonomy, typing methods, and pathogenicity factors. Clin. Microbiol. Rev., 11(4):589-603.

Schutte H., Buchholz R., Gotz P., Schweizer M. and Grafe U. (1997). Isolation techniques. In: Methods in biotechnology (ed. H. Schmauder). International Ltd., Britain; pp.3-105 T.J.

Silipo A., Lanzetta R., Garozzo D., La contore P., Lacobellis N., Molinaro A., Parrilli M., Evidente A. (2002). FBES Journal; 10:2498-2505.

Simoons-Smit A. M., Verweiji-van Vught A. M. J. J. and MacLaren D. M. (1986). The role of $\mathrm{K}$ antigens as virulence factors in Klebsiella. J. Med. Microbiol., 21:133-137.

Straus D.C. (1987). Production of an extracellular toxic complex by various strains of Klebsiella pneumoniae. Infect. Immun., 55:44-48.

Tomas J. M., Benedi V. J., Ciurana B. and Jofre J. (1986a). Role of capsule and O antigen in resistance of Klebsiella pneumoniae to serum bactericidal activity. Infect. Immun., 54(1):85-89.

Wacharotayankun R., Arakawa Y., Ohta M.,
Tanaka K., Akashi T., Mori M. and Kato N. (1993). Enhancement of extracapsular polysaccharide synthesis in Klebsiella pneumoniae by RmpA2, which shows homology to $\mathrm{NtrC}$ and Fix. J. Infect. Immun., 61(8):31643174.

Wang J.H., Liu Y.C., Lee S.S., Yen M.Y., Chen Y.S., Wang J.H., Wann S.R. \& Lin H.H. (1998). Primary liver abscess due to Klebsiella pneumoniae in Taiwan. Clin Infect Dis., 26: 14341438.

Whitaker J.A., Franco-Paredes C., Del Rio C. and Edupuganti S. (2009).Rethinking typhoid fever vaccines: implications for travelers and people living in highly endemic areas. J. Travel Med., 16: 4652.

Williams P., Lambert P.A., Brown M.R.W. and Jones R. J. (1983). The role of the $\mathrm{O}$ and $\mathrm{K}$ antigens in determining the resistance of Klebsiella aerogenes to serum killing and phagocytosis. J. Gen. Microbiol., 129:2181-2191.

Williams P. and Tomas J.M. (1990). The pathogenicity of Klebsiella pneumoniae. Rev. Med. Microbiol., 1:196-204.

Yang C.C., Yen C.H., Ho M.W. \& Wang J.H. (2004). Comparison of pyogenic liver abscess caused by non-Klebsiella pneumoniae and Klebsiella pneumoniae. J Microbiol Immunol Infect., 37: 176-184.

\section{How to cite this article:}

Abeer Ghassan Munther Al-Agha. 2017. Extraction and Purification of Lipopolysaccharide of Klebsiella pneumoniae Isolates. Int.J.Curr.Microbiol.App.Sci. 6(8): 90-100. doi: https://doi.org/10.20546/ijcmas.2017.608.012 